\title{
What the law says about PPE responsibility
}

Andy Cowper uncovers the sometimes conflicting duties of NHS organisations

\author{
Andy Cowper editor \\ Health Policy Insight, London, UK
}

\section{Who is legally responsible for providing personal protective equipment?}

James Down, a partner at the law firm Hempsons, explains that under section 2 of the Health and Safety at Work etc Act 1974 (HSWA) employers have a duty to ensure the health, safety, and welfare at work of all their employees "so far as reasonably practicable."

The duties enshrined in the HSWA reflect the longstanding obligation under common law on employers to take reasonable care to ensure a safe system of work and safe equipment, he says. This includes a duty to provide and maintain equipment, systems of work, and a working environment that are safe and without risks to health.

In addition to the requirements in the HSWA, other health and safety regulations expand on employers' specific duties, including the 1992 Personal Protective Equipment at Work regulations (the PPE Regs). ${ }^{1}$ These state that employers provide staff with suitable personal protective equipment unless risks to their health and safety have been adequately controlled by other means.

So in the NHS, for staff employed on national contracts, the legal responsibility for the supply of PPE sits with the NHS trust or foundation trust that employs them. "Under section 33 of the HSWA, breach of the PPE Regs may amount to a criminal act," Down says.

\section{What are the legal requirements for PPE?}

Down explains that, according to the EU PPE directive that the PPE Regs are supposed to implement into UK law, PPE should be relied on only where the risks posed by work cannot be avoided by other means. But, he says, in the healthcare context the reality is that this "last resort" is often going to be the first line of defence.

The relevant regulations state that, to be suitable, the PPE must be appropriate for the relevant risks and the conditions under which it is used; take account of the user's health, ergonomic requirements, and workstation; fit the user; and be effective in dealing with the risks without increasing the overall risk.

\section{Who is responsible for checking that NHS staff have enough PPE?}

For most workplaces in England and Wales, including hospitals, the regulator for health and safety law is the Health and Safety Executive (HSE). This includes having responsibility for enforcing statutory duties under the HSWA and associated regulations, such as those relating to PPE.

"HSE inspectors have the power to take enforcement action if breaches of the law are found," Down says. Hospitals that breach PPE regulations could be served either an improvement notice or a prohibition notice. "HSE inspectors ... can also bring criminal prosecutions for breaches of health and safety legislation, including for a failure to comply with improvement or prohibition notices," he adds.

\section{Why is no enforcement being carried out?}

Down points out that HSE inspectors typically physically visit workplaces to check compliance with the law, and there is little chance that such visits would take place in the current circumstances.

"It is unlikely that HSE inspectors will be conducting inspections to ensure compliance with the statutory duties to provide PPE to workers," he says. "Inspectors would themselves also need to be provided with PPE in order to be able to safely observe how medical care was being provided."

He also points out that, beyond practical issues, other considerations may mean such visits are not desirable at the moment, as it would mean taking staff away from patient care. "It is unclear whether the public would be supportive of the HSE taking enforcement action against hospitals," he adds.

"Furthermore, a HSE inspector is very unlikely to serve a prohibition notice, because it would prevent the healthcare provider from providing medical care. Therefore, while the HSE 
has the statutory powers to act where employers fail to provide suitable PPE to workers providing medical care, there are practical and political obstacles to the use of HSE's powers of enforcement at the present time."

\section{Can NHS staff take their own action against trusts?}

Adrian Mansbridge, a legal director at the law firm Addleshaw Goddard, says that employers could also face civil claims from employees. "Where employers breach their duty to employees or to the public at large under health and safety law, this may open them up not only to prosecution by regulators but also potentially to civil claims by those who suffer injury as a result, where negligence can be proven and where this can be demonstrated to have given rise to injury on the basis of medical evidence," he says.

\section{With PPE shortages, how can the NHS balance the needs of patients and the safety of staff?}

NHS chief executives are the accountable officers of every trust, and so technically they are responsible for their employees' PPE. But John Coutts, policy adviser for governance at NHS Providers, points out the boards of directors of NHS trusts are facing duties that are pulling in potentially different directions.

"They have both a duty of care to employees and a duty of care to patients under their organisation's care, to whom they must provide appropriate treatment for the patient's condition, which might mean asking staff to do things that in other circumstances they would avoid," he says. "The directors' legal duty of care to the patient is found in various NHS legislation, and also derives from common law."
Coutts says that there is a "potential tension" between a trust's duty to its staff and that to its patients. "The job for directors is to think long and hard about what the balance of these two duties is: to manage and mitigate risks accordingly," he says.

"The well documented issues on PPE bring this into sharp relief. NHS trust leaders are currently thinking and working very hard on risk management processes right now, to ensure staff and patients are safe."

\section{What happens if an employer can't get enough PPE?}

An employer may be unable to obtain PPE despite reasonable effort. Could the employer use what is termed a "force majeure" argument in its defence? "A force majeure clause in effect suspends obligations under the contract and may entitle a party to terminate the contract if the force majeure event is prolonged," explains Bill Gilliam, a partner at Addleshaw Goddard's dispute resolution practice who specialises in healthcare. Whether a force majeure argument applies to a particular contract would depend on the particular clause in the relevant contract and the actual effect of covid-19 on the performance of the contract, Gilliam says. Such clauses can't be implied unless they are specified in the contract, but they can apply to every contract between parties for a supply of goods or services where the contract has a specific force majeure clause.

Competing interests: None declared.

Provenance and peer review: Commissioned; not externally peer reviewed.

1 Health and Safety Executive. Personal protective equipment at work. $2015 \mathrm{https}: / / \mathrm{www}$. hse.gov.uk/pUbns/priced//25.pdf.

Published by the BMJ Publishing Group Limited. For permission to use (where not already granted under a licence) please go to http://group.bmj.com/group/rights-licensing/ permissions 